\title{
側彎 症における矯正力の検討
}

—— 特に casting 時の張力について——

宮崎医科大学整形外科学教室
平 川 川 俊一・田 島 直 也
川 野 桂一郎・脇 山 尚 登
中 村 誠 司・木 村 千 伋

\section{The Study of Corrective Forces at Casting for Scoliosis}

\author{
by
}

\section{Shunichi Hirakawa, Naoya Tajima, Keiichiro Kawano, Naoto Wakiyama, Seiji Nakamura and Chihiro Kimura}

Dept. of Orthopaedic Surgery, Miyazaki Medical College.

\begin{abstract}
Fifteen patients with scoliosis were treated with body cast, simultaneously measured distraction forces and lateral forces. Of these patients, 12 cases had idiopathic scoliosis and 3 had symptomatic scoliosis. There were 13 females and 2 males. Their mean age was 13.9 years old. The cast was applied on Risser frame according to the E. D. F. cast. Distraction forces varied from 20 to $60 \mathrm{~kg}$ (77-114 per cent in comparison with body weight) and lateral forces from 7 to $15 \mathrm{~kg}$ (19-44 per cent). The mean Cobb's angle of the scoliosis in the 15 patients was 46.7 degrees before the cast and 25.4 degrees afters it. They obtained a correction of 45.7 per cent. The correction of the thoracolumbar curve was better than that of the thoracic curve. There was a signi ficant correlation between the correction by cost and by lying. Distraction forces acted more effectively on patients with severe scoliosis.
\end{abstract}

\section{はじめに}

側彎症の治療体系の 中で casting 療法は, 観血的 療法・保存的療法両者にその意義を有している，観血 的療法では術前の preoperative cast としてもちい られ, 脊柱の flexibility を増し, 手術により得られ る矯正をある程度予測できるという点である。また保 存的には brace 療法前に flexibility を増す強力な 手段としてもちいられている.

ての casting 時の長軸方向の牽引力 (distraction force), 側方向の牽引力 (lateral force) は側彎の重 症度により，その有効性が異なっているとの従来の報 告1)4) はあるが， その至適牽引力とあいうべき，一体 何 $\mathrm{kg}$ の力を加えるのが最も効果的で 無䭾がないの か, その答えは出ていないようである.

我々は casting に際して長軸方向の牽引力・側方
向の牽引力を記録し，以上の事柄に答えを求めるべく 検討を行った。

\section{症例および方法}

昭和 56 年 4 月より昭和 59 年 5 月までの間に, 当科 入院のうえ casting を施行されたものは18 症例であ るがそのうち先天性側彎症の 3 例は除外した。 また同 一症例に 1 年以上の間隔をおいて再度 casting を行 ったものもあったので, 15 症例 17 側彎となった。性 別では女性の 13 例, 男性 2 位であり, 平均年令は 13 才11 力月（8２1才）であった. 原因別では特発性側 彎症 12 例，症候性側彎症 3 例であるが，その内訳は Marfan 症候群・neurofibromatosis，そして特異な 顔貌・関節の laxity を伴っているが，診断のついて いない症例各 1 名ずつであった。 casting の方法としては入院のうえ $1 \sim 2$ 週間の 
cotrel 旁引後, E. D. F. 法"2)準じて施行している. 長軸方向の毫引力としては，尾側方向への strap を 両側にあて，骨盤部分を固めたのち，との strap に 重錘をかけた，側方向としては，体幹 stockinette の上から strap をあてバネ計りを介在させて用手的 に旁引した。

レ線計测には cobb 法を用い，立位のものを採用し た。

次に代表例を示す。

症例

\section{〈症例 1〉（図 1)}

16 才女子. 特発性側彎症. brace 療法前のcasting である．矯正前は $\mathrm{Th}_{6 \sim 11}$ が $29^{\circ}$ の側彎を呈していた が，側方向 $10 \mathrm{~kg}$ の牽引条件下でさらに長䩜方向虽引 力 $40 \mathrm{~kg}$ を加えて $12^{\circ}$ 一矯正された. $60 \mathrm{~kg}$ 一增加 させてもこれ以上の改善はみられなかった，最大の効 果が得られる長軸方向の最少牽引力は， $40 \mathrm{~kg}$ かそれ 以下であろう。

〈症例 2〉（図 2)

15 才女子. Marfan 症候群により側彎を呈す. 钼血 的治療の適応であると考えられるが，本人拉よび家族 の同意が得られず casting とbrace 療法で加療する も年々増悪傾向を示している，矯正前 $\mathrm{Th}_{7 \sim 12}$ が $84^{\circ}$ であったが長軸方向の毫引力 $20 \mathrm{~kg}$ にて $62^{\circ}$ 八改善， さらに $40 \mathrm{~kg}$ に増加すると $57^{\circ}$ に改善された。 この 状態にて側方向 $10 \mathrm{~kg}$ の產引力を加えたが，それ以上 の改善はなかった。

以上 15 症例に対して加えた力は，長軸方向の牽引 力は 20〜60 kg（体重比 76.9\%〜114.3\%) 側方向一 は 7〜15 kg（体重比 $19.2 \%$ 43.5\%）であった.

\section{結果}

i）全体执よび curve pattern 毎の成績を検䚯し た（表1）．脊柱の flexibility を示す指標としては 臥位矯正率を採用した。全体としては，矯正前角度 $46.7^{\circ}$ が $25.4^{\circ}$ へ， $45.7 \%$ 矯正率が 得られた。 curve pattern 毎では, single curveにおいては症 例数が少なく，比較するのは困難と思われるが， thoracic curve, thoracolumbar curve 間に矯正前角度 に開きはあっても，卻位矯正率，casting 矯正率とも に差を認めなかった。 double curve に拈いては upper curve, lower curve ともに筒正前角度に差は

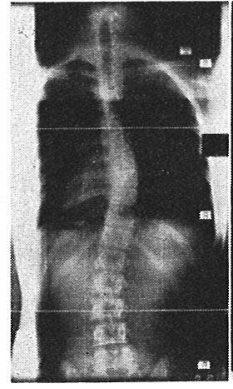

矯正前

$\mathrm{Th}_{6 \sim 11}: 29^{\circ}$
矯正後

$12^{\circ}$

長軸方向 $40 \mathrm{~kg}$ 同 $60 \mathrm{~kg}$

図 1 症例 1

矯正後 $12^{\circ}$

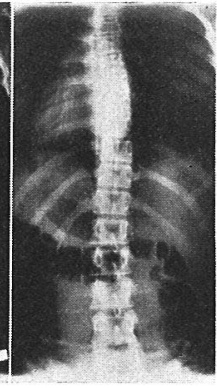

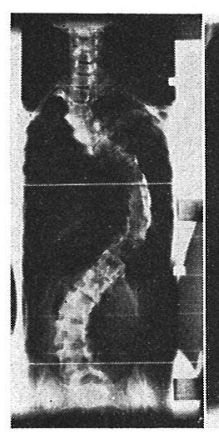

矯正前 $T h_{7 \sim 12}: 84^{\circ}$

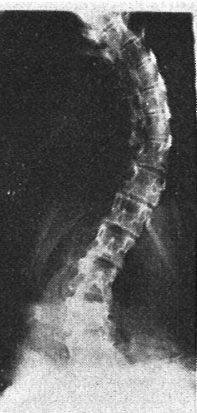

矯正後

$62^{\circ}$

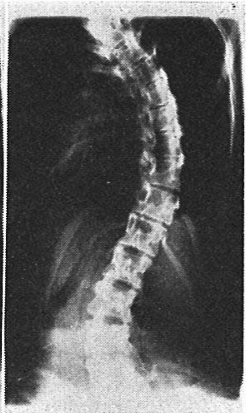

矯正後 $57^{\circ}$ 長軸方向 $20 \mathrm{~kg}$ 同 $40 \mathrm{~kg}$

図 2 症例 2

\begin{tabular}{c|c|c|c|c}
\hline \hline curve pattern & $\begin{array}{c}\text { curve } \\
\text { 数 }\end{array}$ & $\begin{array}{c}\text { 矯正前 } \\
\text { 角 }\end{array}$ & $\begin{array}{c}\text { 卧 } \\
\text { 矯正率 } \\
(\%)\end{array}$ & $\begin{array}{c}\text { casting } \\
\text { 矯正率 } \\
(\%)\end{array}$ \\
\hline total & 17 & $46.7^{\circ}$ & 23 & 45.7 \\
\hline thoracic & 4 & $45^{\circ}$ & 20.8 & 45.0 \\
\hline thoracolumbar & 2 & $27^{\circ}$ & 22.4 & 43.0 \\
\hline double $\mid$\begin{tabular}{l|l|l|} 
upper \\
lower
\end{tabular} & 11 & $\begin{array}{l}44^{\circ} \\
44^{\circ}\end{array}$ & $\begin{array}{c}18.5 \\
25.8\end{array}$ & $\begin{array}{l}32.6 \\
50.6\end{array}$
\end{tabular}

表 1 全体捄よび curre pattern ごとの結果

なかったが，陘位矯正率は lower curve の方が良好 で, casting 矯正率もそれに応じた成績を示した。

ii ） 17 側彎を彎曲の高位により 分類すると, thoracic curve 9 例, thoracolumbar curve 8 例とな り，矯正前角度 $42.8^{\circ}, 51.1^{\circ}$ が casting により 38.9 $\%$ ４9.7\%の矯正を示した（表 1 ）. 


\begin{tabular}{l|c|c|c|c}
\hline \hline curve pattern & $\begin{array}{c}\text { curve } \\
\text { 数 }\end{array}$ & $\begin{array}{c}\text { 矯正前 } \\
\text { 角 } \\
(\%)\end{array}$ & $\begin{array}{c}\text { 卧 位 } \\
\text { 矯正率 } \\
(\%)\end{array}$ & $\begin{array}{c}\text { casting } \\
\text { 矯正率 } \\
(\%)\end{array}$ \\
\hline thoracic curve & 9 & $42.8^{\circ}$ & 20.6 & 38.9 \\
\hline $\begin{array}{l}\text { thoracolumbar } \\
\text { curve }\end{array}$ & 8 & $51.1^{\circ}$ & 25.9 & 49.7
\end{tabular}

表2 curre pattern ごとの結果

\begin{tabular}{c|c|l|l|l}
\hline \hline 重 症 度 & カーブ数 & $\begin{array}{l}\text { 平均年令 } \\
(才)\end{array}$ & $\begin{array}{c}\text { 卧位 } \\
\text { 矯正率 } \\
(\%)\end{array}$ & $\begin{array}{c}\text { casting } \\
\text { 矯 正 率 } \\
(\%)\end{array}$ \\
\hline 31 〜 $30^{\circ}$ & 4 & 15.8 & 21.4 & 36.7 \\
$61^{\circ} \sim$ & 10 & 13.8 & 24.3 & 47.0 \\
& 3 & 12 & 15.1 & 43.7
\end{tabular}

表 3 側彎重症度による結果

iii ）側彎の程度により, 山田に従って 3 群に分類し た (表 3 ). すなわち $30^{\circ}$ 以下の mild 群, $31^{\circ} \sim 60^{\circ}$ の moderate 群, $61^{\circ}$ 以上の severe 群にすると, この 3 群の長軸方向の体重比牽引力は, それぞれ $0.9805 ， 0.9523 ， 0.9410$ と差を認めなかった. 臥位矯 正率は mild 群, moderate 群ではほぼ同等であった が, casting 矯正率では $10 \%$ 以上の差を認めた。 一 方 severe 群では平均年令 12 才と年令の低い傾向が あり, 臥位矯正率はこの群のみ特に低く, flexibility に乏しく rigid な側彎であることを思わせた. しかし casting 矯正率は $43.7 \%$ と mild 群をしのぐ成績が 得られ, 従来より言はれている『長軸方向の毫引力は 側彎の高度な群でより有効に働く』と同様の結果が得 られた。

iv ) 臥位矯正率と casting 矯正率の関係を求めて みると, 図 3 に示すごとく, 臥位矯正率の高い症例に 良好な casting 矯正率が得られており，その相関係 数は 0.6177 であった.

前回我々が本学会で提唱した handing 効果は脊椎 の flexibility を示す指標であり, 今回の 15 症例のう ち 7 症例に handing レ線を撮影し検討したところ, handing 矯正率之 casting 矯正率の相関係数 は 0.3387 であった.

v ）長軸方向および側方向の牽引力と casting 矯 正率との関係を検討してみた. 長軸方向の牽引力（体 重比にて）とcasting 矯正率，同じく側方向との間の 相関係数は低く，一定の傾向は見られなかった，そこ で長軸方向, 側方向衰引力類似の症例を選び片方の牽 引力を一定とした症例間で関係を求めてみたが，明ら かな相関は示さなかった。

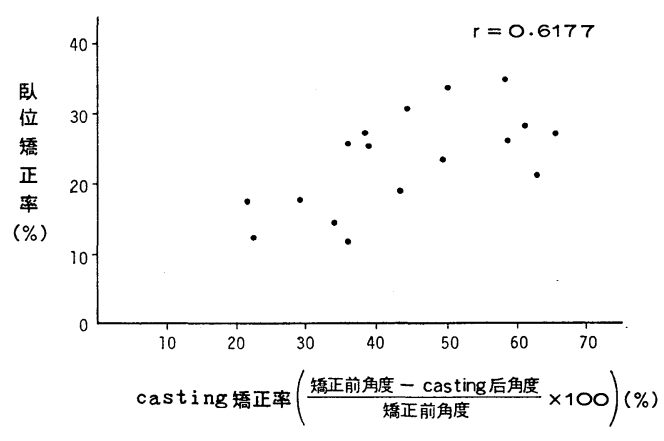

図 3 臥位矯正率と casting 矯正率の相関

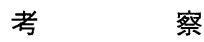

castingにより得られた矯正効果を curve pattern と高位から考えてみた. thoracic curve と thoracolumbar curve の 2 つを比べると thoracolumbar curve の方が矯正前角度は重篤である.また 脊柱に残された flexibility 屯 thoracolumbar curve の方が高い. 得られた casting 矯正群屯 $10 \%$ 以 上 thoracolumbar curve の方が高く，乙の curve pattern の方が矯正しやすいという結果が得られた. この理由として次のように考えられる. thoracic curve では胸椎・肋骨・胸骨の 3 つが 1 つの cage を 形成し，完成した立体を作っているため，外加ら加え られる矯正力に 抵抗性を示すと考えられる，その一 方, thoracolumbar curve $は$ thoracic curve $k$ おける cage が不完全であり，肋骨弓を介しての側方 向からの牽引力, 頭尾側方向からの牽引力屯より効果 的に㗢くのではないかと思われる.

今回我々の得られた結果からは，矯正力として働い た牽引力と casting による矯正率の間に明確な関係 は認められなかった．従って最も効果的でかつ最少に して安全な矯正力を求めることはできなかった．ての 理由として種々の事が考えられる. casting 後に撮影 したレ線を計測したため, casting 内で loss のおてっ た可能性のあるとと，さらにその loss にも症例間で 大小があった可能性があるとと, 各症例間での脊柱の flexibility 側彎の重症度, curve level などのバラ ッキが相関を求める上で影響を及ぼすために一定の傾 向が定まらなかったことなど考えられる．また症例 I に示したでとく矯正可能な限界まで矯正しえた例と， まだ矯正不充分で矯正余地を残した例と混在した集団 で評価したととも挙げられる。 
cast syndrome, 神経系の合併症など我々の例では 見られなかったが，合併症をおこさないような最少の 矯正力で, かつ効果的な矯正力は, 個体間で差はあるに しても原則となるような毫引力として存在するあのと 考える. 今後さらに検討を重ねていきたいと考える.

\section{ま と め}

casting 法を行った 15 症例 17 側彎に対して, その 成績と長軸方向・側方向の牽引力につき検討を加え, 次のような知見を得た。

1) single curve では curve pattern によらず, 臥位矯正率・casting 矯正率は同等であった.

2) double curve では lower curveに高い臥位 矯正率, casting 矯正率を示した.

3) moderate 側彎群で casing 矯正率最大を示 した。

4) 臥位矯正率の悪い severe 側彎群で, 長軸方向 の牽引力はより有効と思われた.

\section{参 考 文 献}

1）国分正一一他：脊柱側彎症と周辺疾患. 整形外 科 Mook. 18: 221-229, 1981.

2) Moe, J. H. et al.: Scoliosis and Other Deformities, Saunders, Philadelphia. 467484, 1978.

3）小野村敏信 - 他：脊柱側彎症と周辺疾患. 整形 外科 Mook, 18: 150-164, 1981.

4）小野敏信 - 他：脊柱側彎症の保存的治療. 日整 会誌, 54:81-92, 1980.

5）小野敏信・他：脊柱側彎症の治療における cotrel 挛引法の適応と意義. 日整会誌, 50：818 $-820,1976$.

6）佐々木邦雄・他：春柱側彎症に招ける術前矯正 訓練法について. 臨整外, 17：447-457，1982.

7）山田憲吾 - 他：脊柱変形. 医学書院, 東京, 1977.

\section{質 問佐賀医科大学 森永 秀和}

頭尾側方向への毫引力は何を目やすとして調節され ているのでしょうか. 我々は, 患者が耐え得る最大限 （2 横指程度の開口が可能な程度）の牽引を働かせて いる.

\section{解 答 宮崎医科大学 平川 俊一}

従来の報告に比べて我々の長軸方向の牽引力は 2 3 倍と大きい.ほぼ体重と同等の牽引力が，患者にと
っては限界と考えられる. cast syndrome をおこし た症例もなかった. casting から Brace に移行した 後の成績は出していない.

質 問総合脊損センター 佐々木邦雄

先生の言われた, 長軸牽引・側彎力とカーブ角度の 関係は cotrel が以前述べていますが，何か他に新し い知見が得られたでしょうか.

casting について, 先に pelvic girdle casting されると述べられましたが，その後はストラップで矯 正され巻き込み方式でしょうか.

解 答宮崎医科大学 平川 俊一

〈質問 1 亿対して〉

cotrel の報告と同様に，高度側彎症に対して長軸 方向の星引力が有効であった. 我々の今回の目的は, 最少の矯正力で最大の効果を求める牽引力を数值とし て，求めたいということであった。

〈"2に対して〉

casting は矯正位を保持してから行なっている。

解 答宮崎医科大学 田島 直也

前回，ブラ下がりによる側彎矯正の効果につき，本 学会で発表したが, 更に casting 時の長軸牽引力, 側方圧迫力の最大の効果を上げる力を求めるため今回 実験を行った，種々の factor があるが，至適力数值 を表わす事が出来れば better と思う.

発 言 九州大学 秋山徹

我々の術前ブランコ㲤引の経験から，カーブの flexibility の必要としては臥位よりも最大側屈による矯 正率がよいと考える．また，牽引力は，体重の1/2 $2 / 3$ 程度が適当であった。

\section{解 答 宮崎医科大学 平川 俊一}

脊柱の flexibility の指標として, 臥位矯正率, hanging 矯正率を用いた. 最大側屈については検討 していない.

質 問 総合脊損センター 角田 信昭 装具療法の最も重要な適応力カーブは何度程度と考 えておられますか。 カーブからいえば私共は $30^{\circ} \sim 40^{\circ}$ のカーブが最も適応が多い場合があると考えていま ఫ. 